\title{
Development and Utilization of Sports Intangible Assets in China under Sustainable Development Perspective
}

\author{
Zhong-qiu Shou ${ }^{*}$ and Ping Liu
}

Department of Physical Education, Hebei Finance University, Baoding, 071000, Hebei, China

\begin{abstract}
Sports intangible assets have no physical form and can be controlled by the sponsor, organizer, and participant of the sports activities, with playing a part in operation of sports industry and bringing economic profits. Under that background of sustainable development of economy proposed in the third plenary session, this paper, by research methods including documentary and logic analysis, based on the classification of sports tangible assets, conducts further research on the value of intangible assets in the tangible assets, analyzes systematically the difficulties in the development and utilization of these intangible assets, and puts forward corresponding development path, which is of great significance to promote the sustainable development of sports intangible assets in China.
\end{abstract}

Keywords: Development, sports intangible assets, sports tangible assets, sustainable development, utilization.

\section{INTRODUCTION}

The third plenary session of the $18^{\text {th }}$ CPC National Congress explicitly pointed out that, we should speed up the transformation of economic development pattern, pace up the construction of an innovative country, and promote the development of economy in a more efficient, fair, and sustainable manner [1-3]. Research on the sustainable development of sports industry has drawn attention from all walks of life. At the same time, literature retrieval result shows that, current researches on sports industry either focus on the sustainable development of sports intangible assets, or the development and utilization of social value of sports tangible assets. However, researches on the value of intangible assets in sports tangible assets are rare [4-6]. Therefore, systematic research on the value of intangible assets in sports tangible assets will play an important role in thickening research theory of sports intangible assets, managing and utilizing sports intangible assets, achieving the seamless connection of the economic value of tangible and intangible assets $[7,8]$, and promoting the sustainable development of sports industry.

\section{TYPES OF SPORTS TANGIBLE ASSETS IN CHINA}

Tangible assets refers to assets in real physical form. Assets in the form of the concrete material products, including production tangible assets and non-production tangible assets. According to this definition, sports tangible assets can be divided into the following types:

\subsection{Sports Competition}

According to the report of GSI launched by Britain's famous sports marketing research organization SPORTCAL, China holds the most large sports competition in the world, based on the top 15 countries in holding 700 international main sports competitions from 2007 to 2018. (refer to Table 1) At the beginning of the 21 st century, China has hosted largescale comprehensive sports events, including 2008 Olympic Games in Beijing, 2010 Asian Games in Guangzhou, 2011 World's Summer University Games, 2014 World's Youth Olympics in Nanjing, 2015 World's Track and Field Championships, 2009 the $11^{\text {th }}$ National Games, and 2013 the $13^{\text {th }}$ National Games. Large sports events leaves tangible assets, including large sports venues and public sports facilities. What's more, the intangible assets [9], including stadium naming rights, architecture design technology, event resource management, and medium renting in these tangible assets are also treasures left by large sports events.

\subsection{Sports Lottery}

Since the end of 1994, China began to issue unified national public welfare sports lottery. After nearly 20 years of development, sports lottery has accumulated more than 6930 hundred million yuan (to December 31, 2013), for example, 1328 hundred million yuan only in 2013. Refer to the following figures for the development of accumulated social and economic wealth of sports lottery (Figs. 1 and 2).

\subsection{Sports Brand}

Statistics show that China's main sports brands includes Li Ning, Anta, and Xtep. Take Anta Sports Products Co., LTD., as an example (see Fig. 3), it pays profit tax since the establishment, contributing intangibly to social development. Featuring high quality and performance, Anta products win lucrative profit and better international status for China during exporting. What's more, Anta helps solving China's employment problem on its development process.

\subsection{Sports Star}

As a tangible assets, sports stars obtain high social reputation during serving, contributing, and repaying society, 
Table 1. Statistics of 700 international sports competitions from 2007 to 2018, launched by SPORTCAL.

\begin{tabular}{|c|c|c|}
\hline Position & Nation & GSI Index Total \\
\hline 1 & China & 55,709 \\
\hline 2 & United Kingdom & 39,393 \\
\hline 3 & Russia & 39,376 \\
\hline 4 & Italy & 38,946 \\
\hline 5 & Canada & 38,094 \\
\hline 6 & Germany & 35,988 \\
\hline 7 & France & 28,587 \\
\hline 8 & Brazil & 28,386 \\
\hline 9 & USA & 25,563 \\
\hline 10 & Netherlands & 23,899 \\
\hline 11 & Spain & 22,744 \\
\hline 12 & Korea & 21,998 \\
\hline 13 & Japan & 20,646 \\
\hline 14 & Turkey & 18,433 \\
\hline 15 & Switzerland & 17,287 \\
\hline
\end{tabular}

with their social value being universally recognized. With the deep development of the marketization and industrialization of sports undertakings, numerous sports stars emerged in China. The emergence of these sports stars provides new angle of the research on the development and expansion of intangible assets.

\section{INTANGIBLE ASSETS IN TANGIBLE ASSETS OF DIFFERENT TYPES}

"Intangible asset refers resources that play a part in production and operation, bring economic benefits, and controlled by a specific body, without physical form." According to this interpretation, sports intangible assets have no physical form and can be controlled by the sponsor, organizer, and participant of the sports activities, with playing a part in operation of sports industry and bringing economic profits. "Undertaking the role of 'capital', sports intangible assets broaden the way for transferring a large number of technological achievements into realistic productivity, promote corporate restructuring and revitalizing other production factors, and provide a wide range of job opportunities."

\subsection{Development Value of Intangible Assets in Sports Competition}

According to the definition of sports intangible assets, naming rights, and cupping rights of large sports competitions, exclusive rights and franchise, lease rights of sports venues and facilities are part of sports intangible assets. The inner value of sports intangible assets of large sports competitions can combine with medias like television and internet

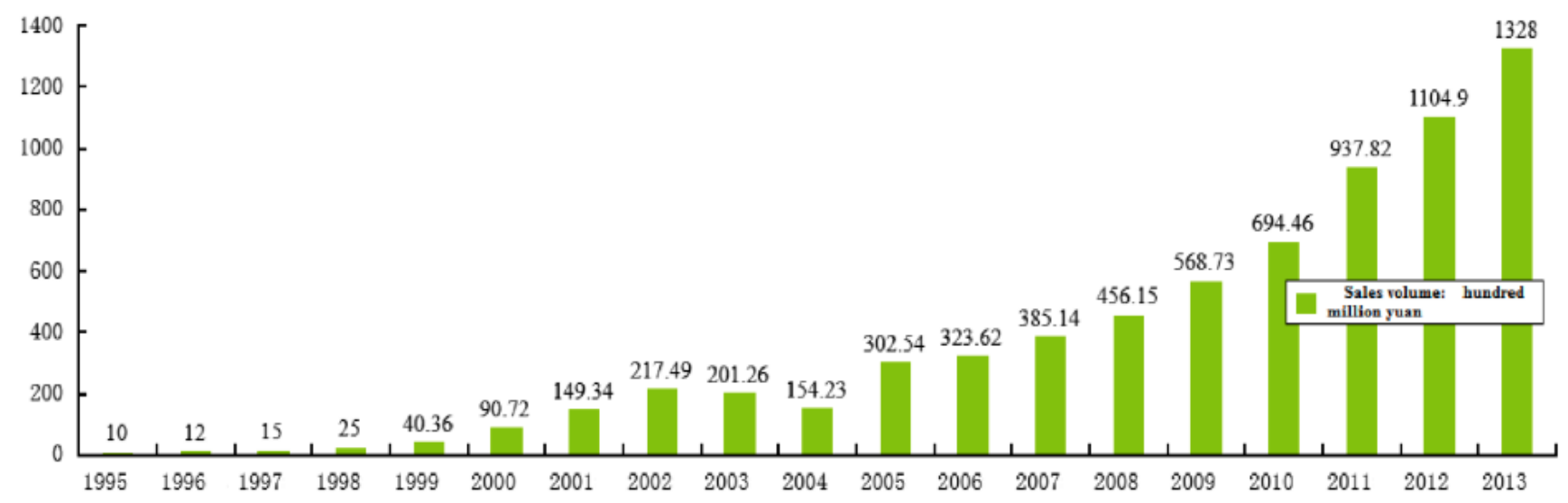

Fig. (1). Sales fund of China sports lottery from 1995 to 2013 (Hundred Million Yuan).

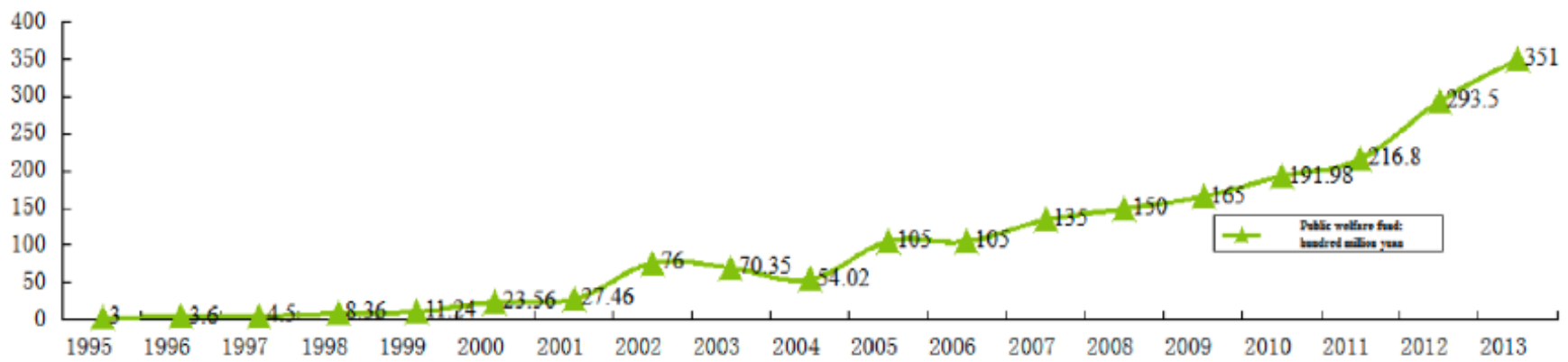

Fig. (2). Sales fund of China sports lottery from 1995 to 2013 (Hundred Million Yuan). 


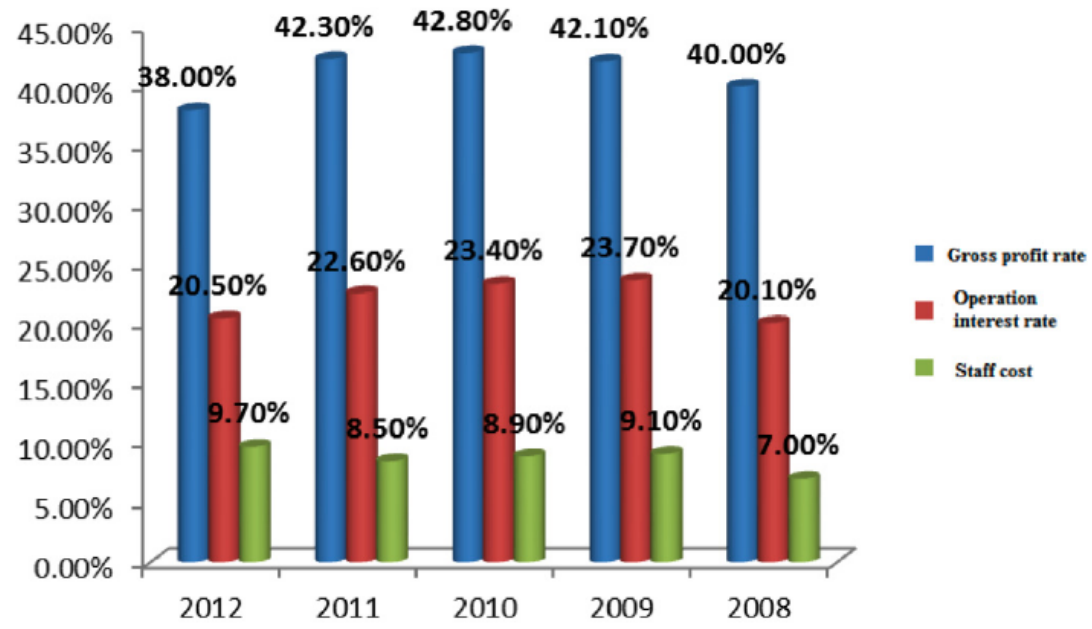

Fig. (3). Gross margin and operational interests of anta from 2008 to 2012.

to make a benign interaction, which make it more easily to attract development of various businesses.

\subsection{Intangible Assets in Sports Lottery}

The intangible assets of sports lottery is mainly reflected in the redistribution of accumulated social capital. It plays an important role in the development of sports cause and social charity cause.

\subsection{Potential Intangible Assets in Sports Brands}

Sports brand enterprises create a large number of intangible assets while creating tangible assets. The social credit of leading sports brand enterprises represents the international position of a country or area, which has important influence on the image of the mentioned country or area. At the same time, the success or failure of the sports brand enterprises cast intangible influences to the increase or decrease of local job opportunities and fiscal revenue.

\subsection{Intangible Value of Sports Stars in Endorsement}

Sports star obtains people's recogition and respect of their social value from endorsements. What's more, the social recognition of the products they endorse is added during the process. While winning high income and social status from endorsements, sports stars also create significant social wealth for products and companies they endorse as well as enterprises and businesses. "Statistics of brands endorsed by Chinese sports stars from Sports Broker show that sports products account for $25 \%$, the largest percent in the products endorsement of sports stars, followed by beverages, which account for 17\%" [7] (Fig. 4).

Endorsement earning of Chinese sports stars is high, with Yao Ming ranks the first among all of the sports stars in China. Based on related statistics, Yao Ming earned \$96.85 million in 2008, in which China Unicom accounts for $\$ 3.85$ million, Apple accounts for $\$ 3$ million, Gatorade accounts for $\$ 5$ million, McDonald's accounts for $\$ 10$ million, and Yuebu accounts for $\$ 75$ million for a ten years agreement. In addition to Yao Ming, the endorsement fees of sports stars like Yi Jianlian and Liu Xiang are also beyond ten million yuan. Sports star endorsements not only increase the income of the players, but also the value of intangible assets.

\section{DIFFICULTIES IN THE DEVELOPMENT AND UTILIZATION OF INTANGIBLE ASSETS IN SPORTS TANGIBLE ASSETS IN CHINA}

First of all, Development of Additional Sports Intangible Assets of Sports Competition in Deep Water;
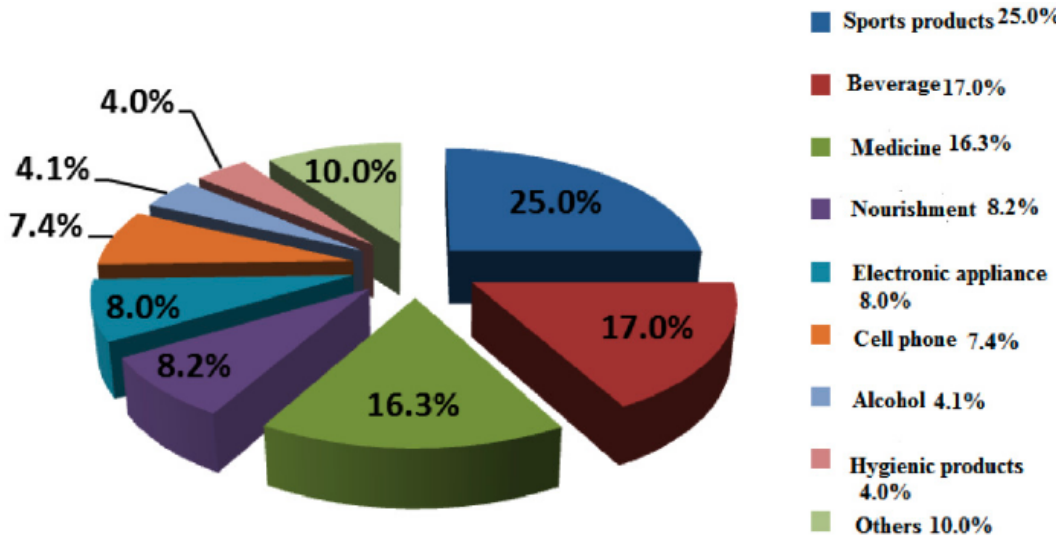

Fig. (4). Endorsement industry scale of sports stars. 
The development of sports assets of sports competitions in China is encountering a lot of difficulties, mainly in the following three aspects: First, sports venues are directly invested by the government of the host city, with the fund from the central government. In this way, the competitions are paid by the taxpayers, which makes it reasonable to open these sports venues to the public for free after the competitions. However, the maintainance cost of these sports venues are high, with the funds from central government stopping with the end of the tournament, plus the ability of local government to maintain these sports venues is limited. Therefore, under the traditional management mode (undertaking major professional league, concerts, and tour), most of the sports venues are difficult to achieve balance, thus failed to meet its true value, such as promoting nationwide fitness programs and creating more profits. According to the recent report of On the Operation and Management Mode and Efficiency of Sports Venues issued by the General Administration of Sports of China, more than $96.6 \%$ of the nearly 100,000 sports venues in China have no source of income. What's worse, most of the sports venues with source of income cannot afford the operation and maintenance fees (Fig. 5).

Second, events rebroadcasting rights and naming rights has not enters the market yet, without quantitative basis for their price. There is still blind spots in laws. The purchase of events rebroadcasting rights and naming rights is almost controlled by the local government of the host city. Third, the patent technology in sports events are often in confidential, failing to get effective development. Fourth, the development of intermediary organizations of sports events is lagging behind, failing to effectively develop the utilization value of sports events.

Second, Vicious Competition in Domestic Sports Brand; Difficulties in Competing with Foreign Brands;

Influenced by global economic downturn and the malicious competition among second-tier sports brands in China, our sports brands are in the age of "crisis". The order quantities and sales of sports brands like Anta, Li Ning, and Xtep are falling, with inventories growing. In order to reduce inventories, $361^{\circ}$ once sold a lot of shoes and clothes in discount, some even as low as eighty percent off. That is to say, the shoes and clothes worth three to four hundred yuan is less than one hundred yuan after discount. Discount of inventories severely impact the sports brand market. The consumption growth brings the reduce of market capacity of new arrivals. In this way, new shoes and clothes which should have large profit cannot achieve the expected sales performance. The whole market is in a vicious circle of competition.

In addition, researches are conducted to the main consumers of sports products -- college students. The research results of 2000 students in Hunan College of Art and Science is shown in Fig. (6). If products of domestic brands and foreign brands like Nike are in the same price, all students in the survey tend to by shoes and clothes of foreign brands. If products of foreign brands are 50 yuan expensive than domestic brands, $98.90 \%$ of the students still tend to buy products of foreign brands. We can tell that China's domestic sports brands have not establish their own brand effect, so that most consumers still tend to by foreign sports shoes and clothes. The propensity to consume is affected by the idea that foreign goods are better and the vanity of "brands and status". What's more, it also reflects that domestic brands cannot compete with foreign brands at the moment.

Third, Spotty Sports Star Endorsements and "Endorsement Crisis";

The number of our sports star endorsement is large, but there are no organized and disciplined companies or departments in place, which leads to the disordered market of sports star endorsement. In addition, influenced by the competition, ethical behavior, and social critics of the sports stars, some brands are seeking endorsements as if they were gambling. Different with entertainment stars, sports star endorsements have more uncertainty. Due to the uncertainties of competition condition, individual ethical behavior, and injury retirement, brands are more careful when seeking for endorsements. All these factors limit the development and utilization of sports intangible assets to some extent.

Fourth, Relatively Large Defects in Laws and Regulations on Sports Intangible Assets in China;

At present, there is only one regulation related to sports intangible assets in Sports Law: "The name, insignia, flag,

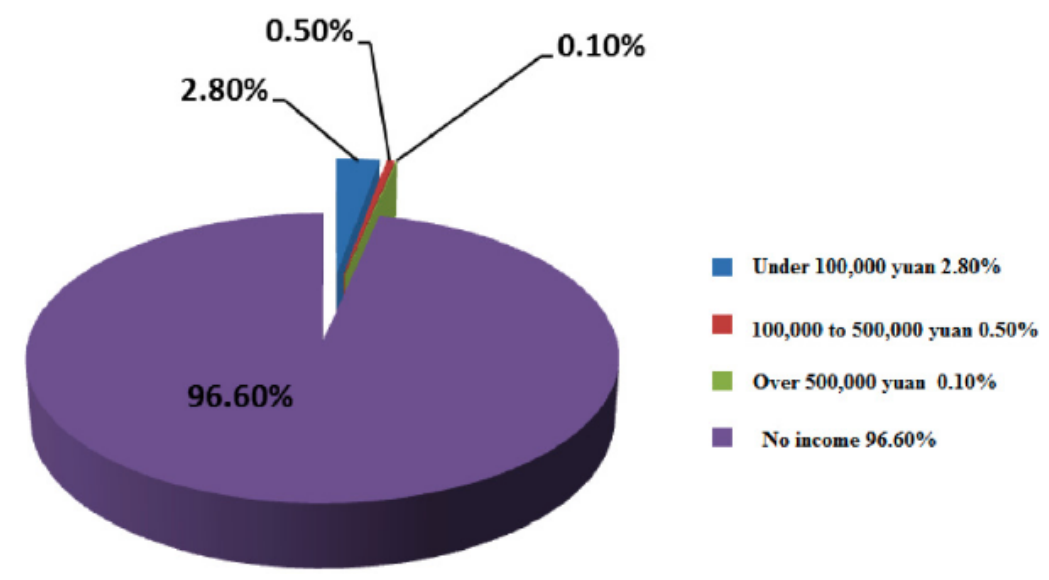

Fig. (5). Operation income proportion of sports venues in China. 


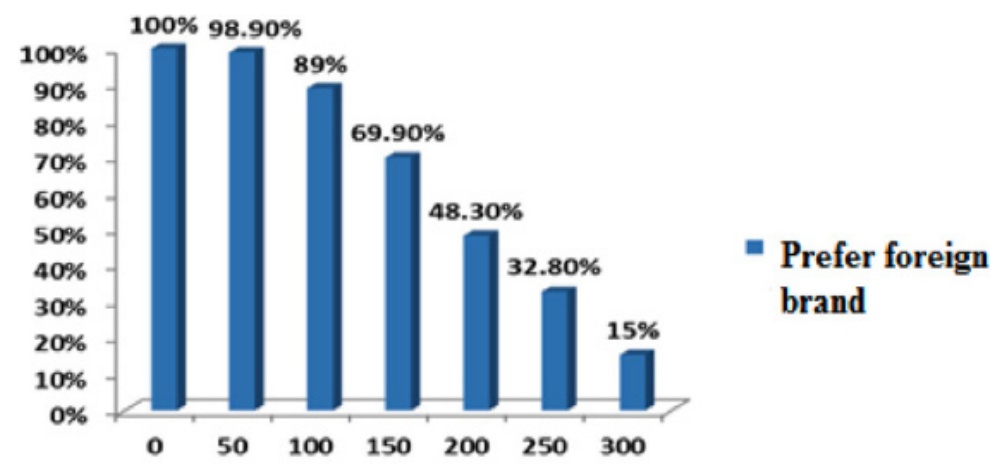

Fig. (6). Consumption tendency of domestic brands and foreign brands like Nike with different price.

and mascot of major sports competitions held in China shall be protected in accordance with the relevant provisions of the state". But the provision is too general, to regulate sports intangible assets in a detailed and clear manner. In addition, there are only principle provisions in related laws and regulations, including Sports Industry Development Outline and Decisions on Strengthening the Construction of Sports Legal System. There are some other regulations on the management of sports intangible assets, which are low level and authority, thus have no substantial influence. The lack of related laws and regulations on the development and utilization of sports intangible assets leaves serious loopholes in the development of sports intangible assets. The development and utilization of the sports intangible assets could not be in accordance with the laws and regulations, which severely restricts the development and utilization of sports intangible assets in our country.

\section{SUSTAINABLE DEVELOPMENT PATH OF THE DEVELOPMENT AND UTILIZATION OF INTANGI- BLE ASSETS IN SPORTS TANGIBLE ASSETS IN CHINA}

As for the difficulties faced by the development of added intangible assets, this paper proposes the following countermeasures, to achieve the sustainable development of sports tangible assets:

First of all, Transfers government function to separate government from sports professional clubs and achieve complete sports competition commercialization;

The current head of major sports events organization is the national Olympic committee, with its supreme authority of general administration of sport of China, which shares the same set of staff. Actually, the national Olympic committee of the western country is a corporation. Related sports are held based on the articles of related associations in a regular manner. Qualified sports professional clubs or businesses get to operate the competitions through bidding, to develop the intangible value of sports competitions. The profit pattern of the Sydney Olympics in 1984 is the best example of sports commercialization. Take China's youth football TV rebroadcasting rights as an example, the Chinese Olympic committee is also undertaken by a corporation, based on the General Principles of the Civil Law of People's Republic of China. However, in practice, it often appears in the face of an administrative organ. The chairman of the Chinese football associa- tion is undertaken by the leader of the general administration of sport of China. The sports TV rebroadcasting rights are owned by the general administration of sport in China or seperate sports associations, which is against market rules. The government intervention leads the intangible assets, including rebroadcasting rights and naming rights into difficulties, without the encouragement of market mechanism.

Second, Strengthens the construction of market credit system of sports brand;

Market mechanism brings evitable vicious competition among various sports companies. But sports brand enterprises always represent the image of a country, a region, or a player. For example, Li Ning represents China in the world as well as reflects the personal charm of the gymnastics prince. If Li Ning company failed to set up market credit image, then its damage is not only a pecuniary loss, but in personality charm, and the trust and respect from the public. Therefore, strengthening the construction of market credit system of sports brands and improving the quality of sports brands play an important role in the sustainable development of sports intangible assets. At the same time, we should pay attention to the quality of domestic brands and the psychological needs of consumers by carrying out patriotic education, strengthening domestic brands, and creating the value of intangible assets.

Third, Establishes and perfects relevant legal system, especially the system of sports brokers, to identify the responsibilities of sports star in business activities:

It requires outstanding sports achievement and function, as well as effective utilization of personal intangible assets to be a good sports star. Every sports star has unique quality, which is the brand personality of the sports star. In China, the endorsement of sports stars in commercial activities started late. Under the socialist market economic system, improvement and perfection of sports broker system will significantly promote the improvement of sports broker industry as well as sports industry. "Baisha event of Liu Xiang" and image rights lawsuit of "high-quality goods shopping guide" are good examples.

In the end,Formulates and issues laws and regulations related to Protection and Development of Sports Intangible Assets, with reference from the west.

Draw lessons from the west as soon as possible in the legislation, to formulate and issue related laws and regula- 
tions on the protection and development of sports intangible assets. In this way, the development and protection of sports intangible assets in tangible assets can be in accordance with the law. For example, it must be specified that the rebroadcasting rights of sports competition televisions shall be protected. The rebroadcasting rights are the backbone of competitive sports industry. Nevertheless, we don't have any related regulations on it, which is not good for the development of our sports industry. Flexible provisions can be made for the ownership of the rebroadcasting rights of sports competitions televisions. But the main ownership shall belong to sports professional clubs. As is regulated in "Copyright Law" of Brazil, the player organizer, such as clubs, owns the economic rights as other performers of literature and art, i.e. allowing or prohibiting others from rebroadcasting or recording the live competitions. Economic compensation should be paid for allowing rebroadcasting or recording, among which, $80 \%$ belongs to the organizer, and $20 \%$ will be split in the players. The above method is worth reference. Although not define the nature of television rebroadcasting rights of sports competitions, the actual ownership of the rights is crystal clear. Therefore, it is worth our reference.

\section{CONFLICT OF INTEREST}

The authors confirm that this article content has no conflict of interest.

\section{ACKNOWLEDGEMENTS}

Declared none.

\section{REFERENCES}

[1] X. Wang, and Q. Gao, "On the Characteristics and Development and Protection Strategy of Sports Intangible Assets," Journal of Beijing Sports University, vol. 28, no. 8, pp. 1029-1030, 2005.

[2] F. Liu, Research on Development Strategy of Chinese Sports Intangible Assets, Beijing Sport University: Beijing, 2001.

[3] M. Zhang, "Study on Capitalization Operation of Intangible Assets," Capital Economic and Trade University: Beijing, 2002.

[4] "Netease Sports China: No. 1 Host of International Sports Events," http://sports. 163.com/12/1115/19/8gcitOnl00051 caqhtml\#p=7r9e6v re4g8f0005, 2012-11-25/2014-02-28.

[5] "General Administration of Sport of China. Report of the Fifth National Sports Ground Survey," http://www.Sport.gov.cn/n16/768/n32454n1167/n2/134749. The HTML, the 2005-02-18/2014$02-28$.

[6] "China Industry Research. Research on Falling Status of Sports Brands like Li Ning and Adidas," Present study http://www. http://www./news/20130813/134415164. HTML.

[7] R. Li, and X. Liu, "Analysis on the problems in sports stars endorsement in China," Journal of Xi'an Sports Institute, vol. 27, no. 3, pp. 284-287, 2010.

[8] L. Zhu, "Causes and Countermeasures of the Loss of Sports Intangible Assets in College in China," Journal of Chongqing Electronic and Engineering Vocational College, no. 5, 2010.

[9] Z. Qiu, and J. Yu, Intangible Assets Marketing of Chinese Olympic Committee, Beijing Sports University Press: Beijing, 2006.

Received: June 10, 2015

Revised: July 29, 2015

Accepted: August 15,2015

(C) Shou and Liu; Licensee Bentham Open.

This is an open access article licensed under the terms of the (https://creativecommons.org/licenses/by/4.0/legalcode), which permits unrestricted, noncommercial use, distribution and reproduction in any medium, provided the work is properly cited. 